\title{
Working identity constructions and workplace learning modes in a global South country: Exploring relations through a narrative approach
}

\author{
Marcelo Afonso Ribeiro \\ University of São Paulo, Brazil
}

\begin{tabular}{|c|c|}
\hline Article Info & Abstract \\
\hline $\begin{array}{l}\text { Article History } \\
\text { Submitted: 16 July } 2018 \\
\text { Revised: } 2 \text { February } 2019 \\
\text { Published online: } 1 \text { April } 2019\end{array}$ & $\begin{array}{l}\text { This research is placed among the current studies discussing the relationship } \\
\text { between working, education and modes of subjectification within the present } \\
\text { context by means of specific phenomena in identity constructions as well as } \\
\text { workplace learning processes. By means of a qualitative narrative research with } \\
\text { in-depth interviews among urban workers in São Paulo, Brazil - a global South } \\
\text { country, this paper aimed to identify and analyse their main narrative patterns } \\
\text { of workplace learning modes and combined to corresponding narrative patterns } \\
\text { of working identity construction previously proposed in the literature. A content } \\
\text { analysis of the narratives of } 40 \text { participants, over } 35 \text { years of age, intentionally } \\
\text { selected, with an approximate distribution of men and women, was carried out. }\end{array}$ \\
\hline $\begin{array}{l}\text { Keywords } \\
\text { Identity } \\
\text { Learning } \\
\text { Labour market } \\
\text { Educational setting } \\
\text { Social constructionism }\end{array}$ & $\begin{array}{l}\text { five corresponding narrative patterns of working identity construction marked } \\
\text { by two opposed movements, equally significant: search for stability and use of } \\
\text { narrative pattern); and search for flexibility and use of informal and relational } \\
\text { learning modes (networking identity narrative pattern). Moreover, the } \\
\text { interrelation between the modes has defined hybrid identity narrative patterns, } \\
\text { and the absence of workplace learning modes has delineated transitory identity } \\
\text { narrative patterns, which is understood as a transitional crisis. In conclusion, } \\
\text { traditional models of identity construction coexist with flexible models, as well } \\
\text { as formal learning modes coexist with informal and relational models. In both } \\
\text { cases hybrid modes arise as a merger or a joint construction between pre- } \\
\text { existing modes. }\end{array}$ \\
\hline
\end{tabular}

\section{Introduction}

The contemporary working world and education settings have changed and have diversified over the past decades. This has happened mainly based on continuous processes of flexibility (Edwards, 1998; Grote \& Raeder, 2009; Sultana, 2013) and fragmentation (Castel, 2009; Kirpal, 2004; Sveningsson \& Alvesson, 2003), which significantly modified the structure and the dynamics of work (Fenwick, 2001; Touraine, 2007) and education (Buchanan, 2015; Carlson, 1998).

In order to attend theses contemporary demands, the current desired profile to the people at large and workers more specifically is basically grounded on personal accountability, agency and

Address of Corresponding Author

Marcelo Afonso Ribeiro, PhD, Instituto de Psicologia, Universidade de São Paulo, Av. Prof. Mello Moraes, 1721, São Paulo-SP, Brasil.

$\triangle$ marcelopsi@usp.br

0000-0002-0396-7693

How to cite: Riberio, M. A. (2019). Working identity constructions and workplace learning modes in a global South country: Exploring relations through a narrative approach. Journal of Pedagogical Research, 3(1), 37-49. doi: 10.33902/JPR.2019.3 
continuous change (Buchanan, 2015; Evetts, 2009; Kelchtermans, 2018). This creates, on the one hand, room for changes and innovations but, on the other hand, instability and insecurity (Castel, 2009; Touraine, 2007). Here it is essential to mention that the same processes have happened in global North as well as in global South (Antunes, 2015; Arulmani, 2011; Blustein, 2011; EspinozaHerold \& González-Carriedo, 2017; International Labour Organization - ILO, 2017; Krein, 2013; Mazawi, 2007; Santos, 2002; Sultana, 2013, 2017).

According to the World Bank (2013), we can socioeconomically and politically divide the world into two large blocks: global North and global South. The former includes the United States, Canada, Western Europe, Australia, New Zealand, and the developed parts of Asia, and the latter Africa, Latin America and developing Asia.

From the outset, it is necessary to stress that "in the postmodern work world, individuals must respond to and interact with ambiguous social opportunities and complex societal offerings" (Savickas, 2015, p. 137), including simultaneous and parallel movements that maintain past models of living focused on stability, homogeneity and linearity, on the one hand, and seek new ways of living based on flexibility, constant change and fluidity, on the other hand (Bardon, Josserand \& Villesèche, 2015; Strangleman, 2012). Moreover, hybrid experiences (Latour, 1993; Sullivan \& Baruch, 2009; Ribeiro, 2015), transitional situations (Carruthers \& Uzzi, 2000; Marhuenda, Martínez \& Navas, 2004; Rascován, 2017) and crisis livingness (Sveningsson \& Alvesson 2003; Touraine, 2007) have emerged in a systematic and more intensively way.

These changes have rearranged not only processes and practices within the working context and educational settings, but also the various dimensions of the living experiences. Some of them have put together both working and educational experiences, such as workplace learning. This is therefore the main reason why we chose this study issue, that is, aiming to understand the close relationships between work and education through the psychosocial phenomenon of workplace learning.

The psychosocial is understood as a process "that is neither 'psychological' nor 'social', but transcends the separation of these elements to create something new" (Frosh, 2013, p. 148) - the psychosocial. It is a shared and continued process of meaning-making and co-construction made by practices, discourses and narratives within a given reality. Thus, workplace learning is considered nor an educational, neither a labour phenomenon, but a working-educational one, where the hyphen is the mark of their inseparability (Ribeiro, 2018).

The workplace learning studies have thereby been renovated and interrelated with other fields of research, such as the studies of identity, in order to continue producing valid and applicable knowledge in educational settings and working contexts. This interrelation has posed three basic issues for the current study: How has workplace learning contemporaneously been taking place? What are the main contemporary working identity constructions? How have these identity constructions performed in these learning processes? Let us see, then, how literature has tried to discuss these issues.

\subsection{Workplace learning}

According to Boud and Garrick (2001), in general, learning and working were traditionally analysed separately and based on different contexts: schools and organisations. Nevertheless, the field of workplace learning has chronologically developed three different analysis and comprehension perspectives. Firstly, it is studied by means of cognitive approaches (Handley, Sturdy, Fincham \& Clark, 2006) based on knowledge acquisition. Secondly, by means of relational learning approaches, it is mainly determined by constructivist notions of sensemaking, which emphasise the relational aspects of learning within communities of practice (Bogenrieder \& Nooteboom 2004; Colley, James, Diment \& Tedder 2003; Wenger, 1998; Farnsworth, Kleanthous \& Wenger-Trayner, 2016), translated into transformative learning (Mezirow, 1997, 2018) according to the reflexive practices (Alvesson, 2001; Spicer, Alvesson \& Kärreman, 2016), and practice-based systemic orientation (Fenwick, 2008, 2014). And, finally, by means of the complexity theory, it 
seeks to understand how activities, knowledge and communities work together in the process of workplace learning (Fenwick, 2008; Fenwick \& Dahlgren, 2015).

According to Garrick (2001), Guile and Griffiths (2000) and Matthews and Candy (2001), there are three dominant discourses of workplace learning which refer to it as processes of knowledge reproduction or individual validation of knowledge, of collective knowledge creation, or of connectivity.

By analysing the different learning types and processes in different contexts, Matthews and Candy (2001) pointed out that the working context fulfils four basic roles: certification of knowledge, problem solving by professional interaction, relational space of exchange and creation of knowledge, and organic space of reproduction.

On the one hand, Fenwick (2001) has already highlighted, two decades ago, the importance of a relational and contextualised conception, in which knowledge is mediated by discourses and the conception thought of as a cultural practice in a working context where identity and diversity would be central factors for workplace learning. These concepts, condensed in the notion of workplace learning as "the continuous and dynamic invention within these relationships that enable a complex system to flourish in changing environments" (Fenwick, 2008, p. 21), are still current trends in the studies of workplace learning, which consider the focus on relationships as a common factor and not on isolated elements of the experience. On the other hand, Billett et al. (2012) pointed out that contemporaneity calls for conciliating different ways of learning for people who have different demands in different contexts. This brings two important issues postulated by Fenwick (2008, p. 17): "how people solve workplace problems through learning" and "understanding how particular groups of workers learn".

According to Handley et al. (2006), workplace learning "is not simply about developing one's knowledge and practice, it also involves the process of understanding who we are and in which communities of practice we belong and are accepted" (p. 644), "including sustaining the interests of one or more groups in the practice" (Billett, 2002, p. 56). To that extent, these were the reasons which has led us to take identity at work as a key aspect to understand the ways in which workplace learning processes usually happen.

\subsection{Working identity construction}

There is a long tradition in the studies of identity, a mediating concept between the self and the other (person and society or I-Other relation), in its distinct dimensions including the identity at work.

We will take the narrative perspective constructed by Savickas (personal communication, July 9, 2014) as a basis to understand identity at work. This perspective stated that identity at work should be seen as a working identity for its dual meaning. On the one hand, it is an identity of those who work, and, on the other hand, it is the working of identity. Through the lens of the social constructionism (Gergen, 1991; McNamee, 2012), we hold a narrative and relational view to identity construction defining it as a relational happening in which one the self, the others and the world are continuously constructed through narratives socially legitimated. In this way, we might focus on the inseparability between self and others in a relational ontology in order to understand identity as a psychosocial construction, that is, a working identity (Alvesson \& Willmott, 2002; Blustein, 2011; Fenwick, 2007; Ribeiro, 2018).

Summing up recent studies carried out by Bardon, Josserand and Villesèche (2015), Fenwick (2007), Grote and Raeder (2009), Strangleman (2012) and Trede (2012), as well as global South studies, such as Ribeiro, Uvaldo and Silva (2016), Soto (2011), Stecher (2012) and Vera and Valenzuela (2012), we may identified some common patterns in the current identity construction processes that can be summarised on three main basis. The first one is the social structure of organisations what has generated the classical organisational identity (Alvesson \& Willmott, 2002; Strangleman 2012). The second one is the embedment in communities of practice what has created the traditional professional and occupational identity (Dubar, 1997; Pratt, Rockmann \& Kaufmann 
2006; Trede, 2012). And, finally, the flexibility and flow of social networks, as stressed by Grote and Reader (2009) and Stecher (2012), what have contemporaneously produced within the social relations a new way of identity construction named as network identity and defined by being inbetween spaces (Fenwick, 2007).

This kind of thinking supposes structuring identities in a small number of the groups uniting around a representative identity pattern or a typology. The use of topologies as an analysis method has been heavily criticised based on the idea that it reduces complex reality to fixed and simplified types. Moreover, "for the most part, such typologies did not engage theoretically with broader social and socio-economic processes in contemporary workforce and society" (Burns, 2015, p. 934).

Burns (2015) highlighted that typologies may opening up interpretive explanatory possibilities and a "more hermeneutic than categorical usage may be the best way forward to avoid the concretising that typologies bring to situations for which they are not entirely appropriate" ( $p$. 947). Layder (1998) complemented this idea by arguing that typologies may foster engagement "in theoretical elaboration and thus to think in terms of chains of reasoning" (p. 73). "Linking theory and data in a dialectical manner opens new uses for typological analysis" (Burns, 2015, p. 942).

Regarding to the questions, we hold the view that the use of typologies should not reduce reality to exclusive types/categories or to "one-to-one correspondences between concepts and data" (Layder, 1998, p. 73). But unlike these ideas, as proposed by Burns (2015), Geels et al. (2016) and Layder (1998), we should focus our studies in the use of typologies as a portray of the reality for analytical and explicatory purposes. To that extent, grounded on a narrative approach, we preferred to use narrative patterns instead of types "understood as the core social discourses about working identity construction emerging from the workers' personal narratives to outline, explore and analyse a contextualised image of the working world" (Ribeiro et al., 2016, p. 239).

We have taken the findings from Ribeiro et al. (2016) to answer the second issue proposed in this paper (What are the main contemporary working identity constructions?),

Based on the existing literature and in a content analysis from working trajectories narratives of a set of 40 Brazilian urban workers, the study identified five narrative patterns of working identity construction.

Basically, participants have constructed their identities by means of narrative patterns described in the literature as organisational identity, professional and occupational identity, and network identity, which are named by Ribeiro et al. (2016) as organisational identity narrative patterns, professional and occupational identity narrative patterns, and networking identity narrative patterns. However, two other patterns have arisen from the analysis and have been unaddressed in the literature: de-identification and hybrid forms, named by the authors, respectively, as transitory identity narrative patterns and hybrid identity narrative patterns. All narrative patterns are in the plural form to highlight that, despite the presence of common structural narrative elements, they did not keep a perfectly homogeneous unit.

The core social discourses from each narrative pattern were stability and security (organisational identity narrative patterns); specialised activity (professional and occupational identity narrative patterns); flexibility, networking and constant change (networking identity narrative patterns); and lack of plan (transitory identity narrative patterns). The hybrid identity narrative patterns were composed by articulating or combining existing elements from the narrative patterns previously described.

Table 1 presents some examples of recording units extracted from the narratives quoted from Ribeiro et al. (2016, p. 246) that have represented each narrative pattern of working identity construction. 
Table 1.

Examples of Narrative Patterns of Working Identity Constructions Recording Units

\begin{tabular}{|c|c|}
\hline $\begin{array}{l}\text { Narrative Patterns of } \\
\text { Working Identity } \\
\text { Construction }\end{array}$ & Recording Units \\
\hline $\begin{array}{l}\text { Organisational identity } \\
\text { narrative patterns }\end{array}$ & $\begin{array}{c}\text { "The company is that manage, the company shall be responsible } \\
\text { for our career" }\end{array}$ \\
\hline $\begin{array}{l}\text { Professional and } \\
\text { occupational identity } \\
\text { narrative patterns }\end{array}$ & $\begin{array}{c}\text { "I have to work on my training area, no matter whether employed } \\
\text { or as a self-employed worker" }\end{array}$ \\
\hline $\begin{array}{l}\text { Networking identity } \\
\text { narrative patterns }\end{array}$ & "Joint permanent jobs with temporary projects" \\
\hline $\begin{array}{l}\text { Transitory identity } \\
\text { narrative patterns }\end{array}$ & $\begin{array}{c}\text { "When you don't know where you want to go, any way will do" } \\
\text { therefore "you're driven by chance" }\end{array}$ \\
\hline
\end{tabular}

These narrative patterns of working identity construction identified from Ribeiro et al. (2016) have been interrelated to the main modes of workplace learning found out in the current study and later presented in this paper.

\subsection{Working identity construction and workplace learning: Relations, interconnections and co- constructions}

Buchanan (2015), Evetts (2009) and Hong, Greene and Lowery (2017) averred that identity is responsible for shaping people and for allowing them to negotiate their place in the world. Kelchtermans (2018) argued that identity would be the outcome of a working practice as well as the future condition for it. And, likewise, Mutch (2003) pointed out that the sense of agency would occur through the distinct modes of participation and identity construction within working contexts.

Klotz, Billett and Winther (2014) assumed that identity plays an integral role in how people learn and perform. And Karmel, Bound and Rushbrook (2013), stating that "learning is identitybuilding work" (p. 5), referred to the profound interrelationship between identity and learning, as well as Billett (2010) to whom the relationship between learning, working and subjectivity assisted in understanding "how individuals direct their learning throughout their working lives" (p. 1).

Therefore, "learning in this way is necessarily shaped by the diverse ways that individuals elect to engage in workplace activities" (Billett, 2010, p. 2), moreover, researchers should investigate how identities are generated and what role learning play in these processes (Billett, Fenwick \& Somerville, 2007).

In a nutshell, working identity operates as basic relational element that provide understanding of the distinguished ways of building the self at work by the means of learning; such ways are impacted by identity constructions. To that extent, working identity construction and workplace learning are closely intertwined and may allow us to provide relevant knowledge about both processes and, in a more extensive fashion, expand the working world understanding.

Thus, drawing on working identity and workplace learning theory and using the narrative approach as a lens, this study aimed to identify, describe and analyse the main workplace learning modes undertaken by urban workers in the city of São Paulo, Brazil - a global South country, and interrelated with the narrative patterns of working identity constructions previously described in Ribeiro et al. (2016).

\section{Method}

The qualitative narrative approach (Polkinghorne, 1988) was the methodology used to coconstruction narratives with the participants and elaborate a taxonomy underpinned by common elements of the set of narratives grouping on categories. This taxonomy was based on the core 
social discourses of participants' narratives about the ways that workplace learning took place. We hold the view that narratives are personal constructions and discourses are collective ones (Brockmeier \& Harre, 2003). Moreover, personal narratives enable to understand how people are shaped by social discourses (Alvesson \& Willmott, 2002). The reliability of the research findings is underlain in the assumption that personal narratives are co-constructed through collective agreements within a community that shares common social discourses which are produced by the exchange of meanings and socialised practices (Denzin, 1989).

\subsection{The socio-occupational context of the participants}

The set of participants came from the city of São Paulo, Brazil, which can be described as a multicultural, globalised and wealthy city with a population of approximately 12 million, responsible for 71,8\% of Brazil's Gross Domestic Product (GDP) and based on industries and services. According to the ILO (2017), recent data by the Brazilian working world and educational settings have showed that its Economically Active Population (EAP) had 15.3\% of people with college education, $53.6 \%$ of them were employed, $37.1 \%$ worked beyond the formal employment bonds, being active in unprotected and unregulated jobs, $13.1 \%$ were unemployed, and $51 \%$ are low qualified workers. In addition, the average income is US\$570.

\subsection{Participants}

Participants were recruited from three different social locations in order to find distinguished profiles: a human resource consultancy, a public agency for labour intermediation and a university career counselling service. All participants were either employed or were performing working activities at the time of the research. The criterion for inclusion in the study was to have a working history of, at least, 18 years, justified by the need to evaluate continuities, changes and crises.

The number of participants had not been set at first, but during the data collection, based on two criteria. First, participant's representativeness for the study; and, secondly, saturation, when narratives begin to repeat (Bardin, 1977). The database from Ribeiro et al. (2016) was used to form the set of participants, aiming nevertheless to explore another research problem. At the end, there were 40 participants, with balanced number of men and women ( $57.5 \%$ men and $42.5 \%$ women), between 40 and 50 years of age (50\%), 18-to-30 years of working history, and with a college degree $(82,5 \%)$. The majority were married $(72.5 \%)$ and employed in private or public companies $(52.5 \%)$ or with mixed careers (30\%), that is, part of it as employees, part of it as self-employed workers.

\subsection{Instruments and procedures}

We asked each participant to construct a free narrative of his/her working career (face-to-face narrative interview method as proposed by Polkinghorne, 1988), and whenever needed, the narrative was questioned by the researcher for the purpose of explanations, unexplored issues, and additional information (Van Langenhove \& Harré, 1993). It is a movement of narrative coconstruction in which the participant tells his/her story (autobiography) that is being rebuilt through researcher interventions (heterobiography). After institutional approval and the consent of participants, the interviews were conducted at the location of the recruitment therefrom, lasted on average 85 minutes and began as a triggering phrase, "Tell me about your working history."

\subsection{Analysis of narratives}

Based on the qualitative narrative approach (Polkinghorne, 1988), a content analysis of the narratives was conducted. It was divided into three stages, aiming to identify common elements of the narratives and to build taxonomy of workplace learning supported by participants' common narrative patterns. The personal narratives worked as a method to detect common narrative patterns (social discourses) of contemporary workplace learning modes (Bardin, 1977; Van Langenhove \& Harré, 1993).

a) Pre-analysis - performing fluctuating reading of each narrative to systematise their contents aiming to understand the core processes of workplace learning modes. 
b) Vertical analysis - identifying key indicators of the narratives of each participant, as well as recording units extracted from the narratives that represented these indicators. The coding was made by three different expert judges to guarantee the process reliability.

c) Horizontal analysis - grouping narratives according to their common content (indicators and recording units), based on the constant comparative method proposed by Strauss and Corbin (1990), and systematising the core social discourses that represent the main workplace learning modes, creating a taxonomy. Here it is essential to mention that the taxonomy produced is a conceptual construct aiming to organise the data for the purpose of identifying narrative patterns, it is not the reality itself.

\section{Results}

Through content analysis, we first present the narrative patterns of workplace learning modes brought by participants along with recording units to exemplify each of them seeking to discuss the first basic issue proposed in this paper (How has workplace learning contemporaneously been taking place?). Secondly, the narrative patterns of workplace learning modes founded were associated to each narrative pattern of working identity construction systematised by Ribeiro et al. (2016), seeking to discuss the third basic issue proposed in this paper (How have these working identity constructions performed in these learning processes?). And, finally, the second basic issue proposed in this paper (What are the main contemporary working identity constructions?) has been answered using data obtained in Ribeiro et al. (2016). In respect of the ethical standards, the author of each submitted recording unit will be identified with a code name to preserve his/her anonymity and in brackets following relevant excerpts from their narratives (e.g., Mary, female, 41, single).

\subsection{Narrative patterns of workplace learning}

First, seeking to answer the first basic issue proposed in this paper (How has workplace learning contemporaneously been taking place?), three narrative patterns of workplace learning have been found out, namely: formal workplace learning narrative patterns offered by training and development organisational system, formal workplace learning narrative patterns offered by specialised educational institutions, and informal and relational workplace learning narrative patterns.

Thus, the formal workplace learning narrative patterns has been defined in a two-fold manner based on who offers learning. First, workplace learning offered by training and development organisational system, and, second, workplace learning offered by specialised educational institutions.

First, in formal workplace learning narrative patterns offered by training and development organisational system, participants sought models of institutional learning, primarily determined by the company where they worked. Sherry (female, 30, single) pointed out, "the company is the identification model for change", "one should enter as an intern and learn (...) must receive guidance to change so that she/he knows where to go". This learning mode would preferably be a formal learning based on reproduction models, as suggested by Herbert (male, 49, married): "the employee development process should always be a linear thing and formally established by the responsible sectors". Although workplace learning can very often stay in the background, as for "stability and security are more important than professional growth" (Arthur, male, 43, married).

Secondly, in formal workplace learning narrative patterns offered by specialised educational institutions, participants have the need for constant learning, which is externally determined and performed in a formal way by means of reproduction models. However, unlike the previous workplace learning narrative patterns, these people sought out this training outside the working context, in specialised educational institutions, as stated by Cindy (female, 39, married): "I came back to take training courses to resume my career", and Mark (male, 58, married): "My commitment is with professional competence in my area, in my profession, so I always search to take refresher and specialisation courses." 
Michael (male, 58, married) asserted that:

I like to know a lot about a subject rather than knowing a little bit about each thing. Therefore, I constantly do specialization courses outside the company that I work for, because the organizational trainings usually add little to my career and I am very innovation-driven.

In this way, pursuit for quality and innovation is an important aim and should be achieved outside the working place in order to develop professional competencies differently from the way in which company used to offer as training.

And, finally, in informal and relational workplace learning narrative patterns, participants mostly sought relational and informal modes of learning, in which they can experience changes and constant reconstructions, because "life should be built by experimentation" (Carl, male, 42, married), and "every time I changed jobs, I didn't have the technical knowledge of the business and had to learn by doing it" (Susan, female, 36, married), justified by the notion that "I have an original work, not formal, so I do my own training" (Nancy, female, 36, single).

The learning-by-doing, learn with competent and more experienced colleagues, and the quest for punctual experiences seem to define this kind of workplace learning.

\subsection{Main modes of workplace learning associated with narrative patterns of working identity construction}

Secondly, seeking to answer the third basic issue proposed in this paper (How have these identity constructions performed in these learning processes), the purpose was to identify the different learning narrative patterns associated with every narrative pattern of working identity construction described.

Participants who constructed an organisational identity narrative pattern preferred to use formal workplace learning narrative patterns offered by training and development organisational system, as showed by Charles (male, 64, married) "Ideally, you would go into a firm and develop within it, go through all the training it offers, take on bigger commitments, earn more, go on a career".

In the organisational identity narrative pattern, it was very clear that security and standardization were two basic principles for career construction, as well as for workplace learning, as indicated by Herbert (male, 49, married):

All changes and transitions over career, as well as the employee development process, should always be a linear thing and formally established by the responsible sectors (...), the important learning just takes place in the training offered by the company.

Participants who constructed a professional and occupational identity narrative pattern have the need for constant learning for their professional development, which is externally determined and performed in a formal way by means of reproduction models. However, unlike the organisational identity narrative patterns, these people preferred to seek out this training outside the working context, in specialised educational institutions, as stated by P17 (male, 58, married): "I always search to take refresher and specialisation courses" (formal workplace learning narrative patterns offered by specialised educational institutions).

Participants who constructed a networking identity narrative pattern mostly sought informal and relational modes of learning, in which they can experience changes and constant reconstructions, as asserted by Carl (male, 42, married): "life should be built by experimentation", and Nancy (female, 36, single): "I do my own training".

The transitory identity narrative patterns, as a pattern of contingency and transition, in general, had no learning models, in contrast, in the hybrid identity narrative patterns, participants combined or intertwined formal and informal learning modes. The former can be exemplified by Tom (male, 41, married), and the latter by Donald (male, 42, single). Tom, who typified a transitory identity narrative pattern, said that: "I have never been able to identify with my working activities, so training does not make sense to me, it's a waste of time". In pursuit of a high specialised and 
qualified development, which was pointed as key issue for people who construct a hybrid identity narrative pattern, Donald (male, 42 , single) argued that:

Currently, in companies, nowadays, you must be adaptable to keep the job that is much-valued (...) and, to be able to keep stability along with adaptability, you should take advantage of both the formal training that the company offers and the everyday workplace learning.

The quest for flexibility, novelties and constant change has emerged in the group of participants as key points for a hybrid identity narrative pattern, which appears to lead to informal and relational learning mode. A good example of that is a brief excerpt of Brenda's (female, 36, married) interview:

When I started my work there, I was a little concerned because some co-workers were there for a long time and I did not wish that for my career, because I need to live by what I like doing, but I also need constant change. To do so, I do all the training that the company offers, as well as I try to take external courses and participate in lectures and workshops whenever possible. I need to be always professionally updated.

\section{Discussion}

The flexibility of working world has generated a diversification in the identity construction strategies and in the workplace learning strategies, though these strategies have still clearly maintained certain characteristics determined by more traditional patterns of their configuration, such as stability, trend towards standardisation and little change (Bardon et al., 2015; Edwards, 1998; Grote \& Reader, 2009). In other words, we have been experiencing transitional situations in which old ways of being and workplace learning coexist with new ones (Grote \& Raeder 2009; Sveningsson \& Alvesson, 2003; Touraine 2007).

Our main findings have confirmed the former statement, since we have realised in the set of participants two opposed and equally significant current narrative movements: the movement of searching for stability and the movement of searching for flexibility, which is a view confirmed by Alvesson \& Willmott (2002), ILO (2017), Sullivan and Baruch (2009), Sultana (2013), and Touraine (2007) in the global North, and by Krein (2013), Ribeiro (2015) and Soto (2011) in the global South, as well as hybrid models (Ribeiro, 2015; Sullivan \& Baruch, 2009) and crisis situations (Castel, 2009).

The results of this study have also corroborated the recommendations of Billett (2010), Billett et al. (2007), Buchanan (2015), Evetts (2009), Hong et al. (2017), Karmel et al. (2013), Kelchtermans (2018), Klotz et al. (2014), and Mutch (2003). They stated that the ways in which people construct their identities assist in understanding the predominant modes those people prefer to learn at work.

Accordingly, confirming also the claims of Billett et al. (2012) and Fenwick (2008), people with different demands in different contexts have the need to conciliate different ways of learning, likewise, the set of participants sought equally opposed modes of learning focused on formal and informal learning modes that, in the working context, were related to different ways of constructing identities.

First, the search for stability generated demand for formal learning modes constructed by formal workplace learning narrative patterns from the participants (organisational, professional and occupational identity narrative patterns), as referred by Alvesson and Wilmott (2002), Dubar (1997), Evetts (2009), Pratt et al. (2009) and Trede (2012). Whereas, secondly, the search for flexibility generated the demand for informal and relational learning modes constructed by informal and relational workplace learning narrative patterns from the participants (networking identity narrative patterns), as argued by Bardon et al. (2015), Billett (2014), Blustein (2011), Buchanan (2015), Edwards (1998), Fenwick (2007), Grote and Raeder (2009) and Kelchtermans (2018). Moreover, thirdly, a demand of articulating or combining the two modes (formal and informal workplace learning narrative patterns) has been generated (hybrid identity narrative patterns), a view confirmed by Carruthers and Uzzi (2000), Latour (1993), Ribeiro (2018), Spicer et al. (2016) and Sullivan and Baruch (2009). And, 
finally, it is also worth noting that crisis and transitional situations have been increasing considerably both in working identity constructions and workplace learning modes (Buchanan, 2015; Rascován, 2017; Strangleman, 2012; Touraine, 2007).

Then, it is essential to highlight that there are patterns in identity constructions and in combined methods of workplace learning, which can be identified, but they show some heterogeneity that claims the attention of business managers and educators. Hence there is a plurality in the demand for different learning processes, ranging from the formally established workplace learning processes, such as training (formal workplace learning narrative patterns offered by training and development organisational system), moving through the formally established in educational institutions, such as training and specialisation courses (formal workplace learning narrative patterns offered by specialised educational institutions), to ways of informal learning in the working environment itself (informal and relational workplace learning narrative patterns) as Billett et al. (2012) and Fenwick (2008) had stressed.

\section{Conclusions and limitations}

Hence, this paper aimed to identify and analyse both working identity constructions associated with the corresponding workplace learning modes that take place between urban workers who live in the city of São Paulo (Brazil).

Firstly, the main workplace learning modes have been identified and, then, associated with each narrative pattern of the systematised identity constructions. In organisational identity constructions, decisive external patterns focused on formal learning modes prevail. In general, these learning modes take place in the reproduction of pre-existing models that are offered primarily by the employing company, such as training courses. In professional and occupational identity constructions, there is also the predominance of external patterns that, by means of pre-existing models of reproduction, are decisive in formal learning, even though the search for external training in specialised educational institutions prevails. In hybrid identity constructions, formal and informal learning models are interrelated or interlaid, while in transitory identity constructions there are no learning models.

In short, as literature has pointed out, contemporaneity has been calling for conciliating different narrative patterns of constructing the self in the world (Antunes, 2015; Bardon et al., 2015; Buchanan, 2015; Rascován, 2017; Ribeiro et al., 2016) as well as learning modes for people with distinguished needs in different contexts (Billett, 2014; Fenwick \& Dahlgren, 2015; Kelchtermans, 2018; Mezirow, 2018). Therefore, it is important to interrelate working identity constructions and workplace learning modes in order to understand the working-educational dynamics, contexts, relations and settings in the contemporary.

Although the implications of our study seem to be relevant, our research has its limitations, because it comprises only participants from one single context and does not represent the entire São Paulo residents. Nevertheless, it has potential of giving insight into how Brazilian people build their working identities and prefer to learn at workplace in a predominantly vulnerable context.

\section{References}

Alvesson, M. (2001). Knowledge work: Ambiguity, image and Identity. Human Relations, 54(7), 863-886. doi: $10.1177 / 0018726701547004$

Alvesson, M., \& Willmott, H. (2002). Identity regulation as organizational control: Producing the appropriate individual. Journal of Management Studies, 39(5), 619-644. doi: 10.1111/1467-6486.00305

Antunes, R. (2015). The new morphology of the working class in contemporary Brazil. Socialist Register, 51, 178-198.

Arulmani, G. (2011). Striking the right note: The cultural preparedness approach to developing resonant career guidance programmes. International Journal for Educational and Vocational Guidance, 11, 79-93. doi: 10.1007/s10775-011-9199-y 
Bardin, L. (1977). L'analyse de contenu [Content analysis]. Paris: PUF.

Bardon, T., Josserand, E., \& Villesèche, F. (2015). Beyond nostalgia: Identity work in corporate alumni networks. Human Relations, 68(4), 583-606. doi: 10.1177/0018726714532967

Billett, S. (2002). Critiquing workplace learning discourses: Participation and continuity at work. Studies in the Education of Adults, 34(1), 56-67. doi: 10.1080/02660830.2002.11661461

Billett, S. (2010). Lifelong learning and self: Work, subjectivity and learning. Studies in Continuing Education, 32(1), 1-16. doi: 10.1080/01580370903534223

Billett, S. R. (2014). Securing intersubjectivity through interprofessional workplace learning experiences. Journal of Interprofessional Care, 28(3), 206-211. doi: 10.3109/13561820.2014.890580

Billett, S., Fenwick, T., \& Somerville, M. (Eds.). (2007). Work, learning and subjectivity. New York, NY: Springer.

Billett, S., Henderson, A., Choy, S., Dymock, D., Beven, F., Kelly, A., ... Smith, R. (2012). Change, work and learning: Aligning continuing education and training. Working paper, NCVER, Adelaide, AU.

Blustein, D. L. (2011). A relational theory of working. Journal of Vocational Behavior, 79(1), 1-17. doi: 10.1016/j.jvb.2010.10.004

Bogenrieder, I., \& Nooteboom, B. (2004). Learning groups: What types are there? A theoretical analysis and an empirical study in a consultancy firm. Organization Studies, 25(2), 287-313. doi: $10.1177 / 0170840604040045$

Boud, D., \& Garrick, J. (2001). Understandings of workplace learning. In D. Boud \& J. Garrick (Eds.), Understanding learning at work (pp. 1-11). London, UK: Routledge.

Brockmeier, J., \& Harré, R. (2003). Narrativa: problemas e promessas de um paradigma alternativo [Narrative: Issues of an alternative paradigm]. Psicologia: Reflexão e Crítica, 16(3), 525-535.

Buchanan, R. (2015). Teacher identity and agency in an era of accountability. Teachers and Teaching, 21(6), 700-719. doi.org/10.1080/13540602.2015.1044329

Burns, E. (2015). Re-imagining career transition: What help from typologies?. Journal of Sociology, 51(4), 933949. doi: $10.1177 / 1440783313486191$

Carlson, D. (1998). Power/knowledge/pedagogy. New York, NY: Routledge.

Carruthers, B., \& Uzzi, B. (2000). Economic sociology in the new millennium. Contemporary Sociology, 29(3), 486-494. doi: $10.2307 / 2653936$

Castel, R. (2009). La montée des incertitudes [The increased uncertainty]. Paris: Seuil.

Colley, H., James, D., Diment, K., \& Tedder, M. (2003). Learning as becoming in vocational education and training: Class, gender and the role of vocational habitus. Journal of Vocational Education \& Training, 55(4), 471-498. doi: 10.1080/13636820300200240

Denzin, N. (1989). Interpretive biography. Newbury Park, CA: Sage.

Dubar, C. (1997). La socialisation, construction des identités sociales et professionnelles [Socialization, construction of social and professional identities]. Paris, France: Armand Colin.

Edwards, R. (1998). Flexibility, reflexivity and reflection in the contemporary workplace. International Journal of Lifelong Education, 17, 377-388. doi: 10.1080/0260137980170604

Espinoza-Herold, M., \& González-Carriedo, R. (2017). Issues in Latino education. New York, NY: Taylor \& Francis.

Evetts, J. (2009). The management of professionalism: A contemporary paradox. In S. Gerwirtz, P. Mahony, I. Hextall, \& A. Cribb (Eds.), Changing teacher professionalism: International trends, challenges and ways forward (pp. 19-30). Abingdon, UK: Routledge.

Farnsworth, V., Kleanthous, I., \& Wenger-Trayner, E. (2016). Communities of practice as a social theory of learning: A conversation with Etienne Wenger. British Journal of Educational Studies, 64(2), 139-160. doi: 10.1080/00071005.2015.1133799

Fenwick, T. J. (2001). Tides of change: New themes and questions in workplace learning. New Directions for Adult and Continuing Education, 92, 3-17. doi: 10.1002/ace.36

Fenwick, T. J. (2007). Knowledge workers in the in-between: network identities. Journal of Organizational Change Management, 20(4), 509-524. doi: 10.1108/09534810710760054

Fenwick, T. J. (2008). Workplace learning: Emerging trends and new perspectives. New Directions for Adult and Continuing Education, 119, 17-26. doi: 10.1002/ace.302

Fenwick T. J. (2014). Assessment of professionals' continuous learning in practice. In S. Billett, C. Harteis \& H. Gruber (Eds.), International handbook of research in professional and practice-based learning. Cham, Switzerland: Springer. 
Fenwick, T., \& Dahlgren, M. A. (2015). Towards socio-material approaches in simulation-based education: Lessons from complexity theory. Medical Education, 49(4), 359-367. doi: 10.1111/medu.12638

Frosh, S. (2012). Psychosocial theory. In T. Teo (Ed.), Encyclopedia of critical psychology (pp. 144-149). New York, NY: Springer.

Garrick, J. (2001). The dominant discourses of learning at work. In D. Boud, \& J. Garrick (Eds.), Understanding learning at work (pp. 216-231). London, UK: Routledge.

Geels, F. W., Kern, F., Fuchs, G., Hinderer, N., Kungl, G., Mylan, J., ... \& Wassermann, S. (2016). The enactment of socio-technical transition pathways: A reformulated typology and a comparative multi-level analysis of the German and UK low-carbon electricity transitions (1990-2014). Research Policy, 45(4), 896913. doi: 10.1016/j.respol.2016.01.015

Gergen, K. J. (1991). The saturated self: Dilemmas of identity in contemporary life. New York, NY: Basic Books.

Grote, G., \& Raeder, S. (2009). Careers and identity in flexible working. Human Relations, 62(2), 219-244. doi: $10.1177 / 0018726708100358$

Guile, D., \& Griffiths, T. (2000). Learning through work experience. London, UK: Lifelong Learning.

Handley, K., Sturdy, A., Fincham, R., \& Clark, T. (2006). Within and beyond communities of practice: Making sense of learning through participation, identity and practice. Journal of Management Studies, 43(3), 641-653. doi: 10.1111/j.1467-6486.2006.00605.x

Hong, J., Greene, B., \& Lowery, J. (2017). Multiple dimensions of teacher identity development from preservice to early years of teaching: a longitudinal study. Journal of Education for Teaching, 43(1), 84-98. doi.org/10.1080/02607476.2017.1251111

International Labour Organization (2017). World employment and social outlook: Trends 2017. Geneva, Switzerland: International Labour Organization.

Karmel, A., Bound, H., \& Rushbrook. P. (2013). Identity and learning for freelance adult educators in Singapore. Singapore, SG: Institute for Adult Learning.

Kelchtermans, G. (2018). Professional self-understanding in practice: Narrating, navigating and negotiating. In P. A. Schutz, J. Hong \& D. C. Francis (Eds.), Research on teacher identity (pp 229-240). Cham, Switzerland: Springer.

Kirpal, S. (2004). Researching work identities in a European context. Career Development International, 9(3), 199-221. doi: 10.1108/13620430410535823

Klotz, V. K., Billett, S., \& Winther, E. (2014). Promoting workforce excellence: formation and relevance of vocational identity for vocational educational training. Empirical research in vocational education and training, 6(1), 1-20. doi: 10.1186/s40461-014-0006-0

Krein, J. D. (2013). As transformações no mundo do trabalho e as tendências das relações de trabalho na primeira década do século XXI no Brasil [The changes in the working world and trends of labor relations in the first decade of the 21st century in Brazil]. Revista NECAT, 2(3), 6-25.

Latour, B. (1993). We have never been modern. Cambridge, MA: Harvard University Press.

Layder, D. (1998). Sociological practice: Linking theory and social research. London, UK: Sage.

Marhuenda, F., Martínez, I., \& Navas, A. (2004). Conflicting vocational identities and careers in the sector of Tourism. Career Development International, 9(3), 222-244. doi: 10.1108/13620430410535832

Matthews, J. H, \& Candy, P. C. (2001). New dimensions in the dynamics of learning and knowledge. In D. Boud \& J. Garrick (Eds.), Understanding learning at work (pp. 47-64). London, UK: Routledge.

Mazawi, A. E. (2007). 'Knowledge society' or work as 'spectacle'? Education for work and the prospects of social transformation in Arab societies. In L. Farrell \& T. Fenwick (Eds.), Educating the global workforce: Knowledge, knowledge work and knowledge workers. London, UK: Routledge.

Mcnamee, S. (2012). From social construction to relational construction: Practices from the edge. Psychological Studies, 57(2), 150-156. doi: 10.1007/s12646-011-0125-7

Mezirow, J. (1997). Transformative learning: Theory to practice. New Directions for Adult and Continuing Education, 74, 5-12. doi: 10.1002/ace.7401

Mezirow, J. (2018). Contemporary theories of learning. London, UK: Routledge.

Mutch, A. (2003). Communities of practice and habitus: A critique. Organization Studies, 24(3), 383-401. doi: $10.1177 / 0170840603024003909$

Polkinghorne, D. E. (1988). Narrative knowing and the human sciences. Albany, NY: State University of New York Press.

Pratt, M. G., Rockmann, K. W., \& Kaufmann, J. B. (2006). Constructing professional identity: The role of work and identity learning cycles in the customization of identity among medical residents. Academy of Management Journal, 49(2), 235-262. doi: 10.5465/amj.2006.20786060 
Rascován, S. (2017). Orientación vocacional con sujetos vulnerabilizados: Experiencias sociocomunitarias en los bordes [Career counseling with vulnerable subjects: Socio-community experiences at the edges]. Buenos Aires, Argentina: Noveduc.

Ribeiro, M. A. (2015). Contemporary patterns of career construction of a group of urban workers in São Paulo (Brazil). Journal of Vocational Behavior, 88, 19-27. doi: 10.1016/j.jvb.2015.02.008

Ribeiro, M. A. (2018). Reflecting upon reality in a psychosocial manner: Social constructionist challenges for the fields of career guidance and counseling (CGC) and work and organizational psychology (WOP). In A. M. Columbus (Ed.), Advances in psychology research. Vol. 132 (pp. 113-143). New York, NY: Nova.

Ribeiro, M. A., Uvaldo, M. C. C., \& Silva, F. F. (2016). Impact of gender relations on the narrative patterns of working identity constructions: A case study with Brazilian urban workers. Journal of Counsellogy, 5, 237256.

Santos, B. S. (2002). Toward a multicultural conception of human rights. In B. Hernandez-Truyol (Ed.), Moral imperialism: A critical anthology (pp. 39-60). New York, NY: New York University Press.

Savickas, M. L. (2015). Career counseling paradigms: Guiding, developing, and designing. In P. J. Hartung, M. L. Savickas \& W. B. Walsh (Eds.), APA handbook of career intervention: Vol. 1. Foundations (pp. 129-143). Washington, DC: American Psychological Association.

Soto, A. (2011). Narrativas de profesionales chilenos sobre sus trayectorias laborales: la construcción de identidades en el trabajo [Narratives of Chilean professionals about their working trajectories: The construction of identities at work]. Psykhe, 20(1), 15-27. doi:10.4067/S0718-22282011000100002

Spicer, A., Alvesson, M., \& Kärreman, D. (2016). Extending critical performativity. Human Relations, 69(2), 225-249. doi: 10.1177/0018726715614073

Stecher, A. (2012). Perfiles identitarios de trabajadores de grandes empresas del retail en Santiago de Chile: aportes psicosociales a la comprensión de las identidades laborales [Identity profiles of workers in large retail companies in Santiago, Chile: Psychosocial contributions to the understanding of labor identities]. Psykhe, 21(2), 9-20. doi: 10.7764/psykhe.21.2.538

Strangleman, T. (2012). Work identity in crisis? Rethinking the problem of attachment and loss at work. Sociology, 46(3), 411-425. doi: 10.1177/0038038511422585

Strauss, A., \& Corbin, J. M. (1990). Basics of qualitative research: Grounded theory procedures and techniques. London, UK: Sage.

Sullivan, S. E., \& Baruch, Y. (2009). Advances in career theory and research: A critical review and agenda for future exploration. Journal of Management, 35(6), 1542-1571. doi: 10.1177/0149206309350082

Sultana, R. G. (2013). Flexibility and security? 'Flexicurity' and its implications for lifelong guidance. British Journal of Guidance E Counselling, 41(2), 145-163. doi: 10.1080/03069885.2012.721125

Sultana, R. G. (Ed.). (2017). Career guidance and livelihood planning across the Mediterranean challenging transitions in South Europe and the MENA region. Rotterdam, The Netherlands: Sense.

Sveningsson, S., \& Alvesson, M. (2003). Managing managerial identities: Organizational fragmentation, discourse and identity struggle. Human Relations, 56(10), 1163-1193. doi: 10.1177/00187267035610001

Touraine, A. (2007). New paradigm for understanding today's world. Cambridge, UK: Polity.

Trede, F. (2012). Role of work-integrated learning in developing professionalism and professional identity. Asia-Pacific Journal of Cooperative Education, 13(3), 159-167.

Van Langenhove, L., \& Harré, R. (1993). Positioning and autobiography: Telling your life. In N. Coupland, \& J. F. Nussbaum (Eds.), Discourse and lifespan identity (pp. 81-99). London, UK: Sage.

Vera, N. J. A., \& Valenzuela, M. J. E. (2012). El concepto de identidad como recurso para el estudio de transiciones [Identity as a conceptual resource for the study of transitions]. Psicologia $\mathcal{E}$ Sociedade, 24(2), 272-282. doi: 10.1590/S0102-71822012000200004

Wenger, E. (1998). Communities of practice: Learning, meaning and identity. Cambridge, UK: Cambridge.

World Bank (2013). World development indicators 2013. Washington, DC: World Bank. doi: 10.1596/978-0-82139824-1. 